\title{
A Patient Having Multiple Fruit-Vegetable Allergies Presenting with Abdominal Pain
}

\author{
Karın Ağrısı Şikayeti ile Başvuran Hastada Çoklu Sebze-Meyve Alerjisi
}

\author{
(1) Öner Özdemir
}

Sakarya University Training and Research Hospital, Clinic of Pediatrics, Division of Allergy and Immunology, Sakarya, Turkey

\begin{abstract}
Allergy to fruits and vegetables are the most frequent food allergies in adolescents and adults. The most common phenotypes of fruit and vegetable allergy are pollen-food allergy syndrome (PFAS) (oral allergy syndrome) and lipid transfer protein (LTP) syndrome. In PFAS, fruit and vegetable allergy is caused by a prime sensitization to labile pollen allergens, e.g. Bet $v 1$ or profilin, and yielding generally mild phenotype, is made of local oropharyngeal symptoms. However, LTP syndrome occurs from a sensitization to LTPS, which are stable plant food allergens, often resulting systemic allergic reactions and moreover anaphylaxis. Componentresolved molecular diagnosis is crucial in directing the treatment of these patients. Existing therapeutic policies involve prevention and salvage medication, including epinephrine, for life-threatening LTP allergic reactions. Allergen specific pollen immunotherapy is not found to be helpful to manage PFAS, nevertheless sublingual immunotherapy against LTPs appears to be an encouraging treatment. Here, an interesting patient having abdominal pain for a long period of time whom later diagnosed by us with PFAS is discussed under the light of recent literature.
\end{abstract}

Keywords: Abdominal pain, vegetable, fruit, profilin, food allergy

\section{ÖZ}

Meyve ve sebzelere alerji, ergen ve erişkinlerde en sık rastlanan besin alerjisidir. Meyve ve sebze alerjisinin en sık görülen klinik șekli (fenotipi) polen-besin alerji sendromu (PFAS) (oral alerji sendromu) ve lipid transfer protein (LTP) sendromudur. PFAS'de, meyve ve sebze alerjisi dayanıksız (labil) Bet v 1 veya profilin gibi polen alerjenlerine primer duyarlașma ile meydana gelir ve genellikle lokal orofaringeal semptomlarla giden hafif bir fenotipe yol açar. Fakat LTP sendromu, stabil bitki besin alerjeni olan LTP duyarlaşmasına bağlı oluşur ve sıklıkla sistemik alerjik semptomlara ve daha fazlası anafilaksiye yol açabilir. Bu hastaların tedavisini yönlendirmede, bileșenedayalı moleküler teşhis yöntemi esastır. Mevcut tedavi stratejileri alerjenden korunma ve yaşamı tehdit eden LTP alerjik reaksiyonlarında epinefrin gibi kurtarıcı ilaç kullanımını içerir. Allerjen spesifik polen immünoterapisi PFAS'nin tedavisinde yararlı bulunmamış olmakla beraber, LTP'lerine karşı verilen sublingual immünoterapi ümit vadetmektedir. Burada, uzun süredir karın ağrısı olan ilginç bir hastanın PFAS tanısı konulması güncel literatür veriler ıșığında tartışılacaktır.

Anahtar Kelimeler: Karın ağrısı, sebze, meyve, profilin, besin alerjisi

\section{Introduction}

Fruit and vegetable allergy is the most common food allergy in adolescents and adults (1-3). Multiple vegetable-fruit allergy is manifested by panallergen [profilin, lipid transfer proteins (LTP), etc] sensitivity (sensitization) in children and is reported to be common in the literature $(1,2)$. Fruit-vegetable allergy occurs as a result of primary sensitization to the food or pollen allergen containing the panallergen (4).

Panallergen sensitivity is most commonly encountered in forms called pollen-food allergy syndrome (PFAS)/oral allergy syndrome (OAS) or LTP syndrome (5-8). PFAS results from primary sensitization to labile pollen allergens such as Bet v 1 or Profilin. Profilin is found in pollen and foods, and it causes food allergy as a result of sensitivity to labile allergen as a result of exposure to pollen from the respiratory tract. Ingestion of related food cross-reacting with pollen creates the PFAS phenotype with mild and local oropharyngeal reactions, and as a result, allergy to plantderived foods usually develops. For example, there is a 55\% chance of cross-reaction between birch and ragweed pollen and peach, apple and melon (1,2). LTP syndrome, on the other hand, causes food allergy due to a reaction to heat and enzymatic treatment stable allergens of non-pollen-related plant-derived foods. It often causes a more severe systemic and/or anaphylactic type of allergic reaction $(8,9)$. 
Here, we describe the presentation and evaluation of a patient to our allergy outpatient clinic, with multiple vegetable-fruit allergy-related abdominal pain due to the development of PFAS, which we believe to have occurred as a result of sensitization of the panallergen profile.

\section{Case Report}

A 10-year-old male patient has complaints of abdominal pain and constipation since infancy, and he has had swelling of his eyes and lips (angioedema) in the last 3-4 years, during periods of increased abdominal pain and in spring months. In particular, the patient, whose relation with a food or nutrition could not be clearly defined, and who applied to the emergency department due to swelling of the eyes and lips, did not have urticarial rash at the same time. It was not evaluated as anaphylaxis or a similar clinical manifestation, and the swelling regressed with antihistamine treatment. The patient, who was examined inpatient and outpatient due to abdominal pain, was referred to the pediatric gastroenterology and pediatric rheumatology departments for examination purposes. No abnormal rheumatological or gastroenterological findings were detected in the examinations evaluated in two different centers. FMF gene analysis was negative. The patient was referred to the pediatric allergy clinic for evaluation due to swelling of the lips and eyes. According to the patient's anamnesis, there were also symptoms consistent with mild intermittent allergic rhinitis. There were no other features in the clinical and family history. The physical examination performed at the time of admission to the service was also completely normal.

In the skin prik tests of the patient, the tree pollen panel (cypress, sycamore, ash); cereal and grass pollen panel (various types of grasses, including English grass, Chenopodium, meadow grass) were found to be positive. A specific immunoglobulin E (IgE) scan was performed for dust mixture and other inhaled pollen related to the respiratory tract. A specific IgE value of $>100 \mathrm{ku} / \mathrm{L}$ was found in the screening for inhaled allergens related to respiration, and a specific IgE value of 0.2 $\mathrm{ku} / \mathrm{L}$ was found for the dust mixture. After the patient's complaints of abdominal pain were mostly after meals, a food allergy due to PFAS was suspected. Specific IgE values were examined for foods that the family suspected. According to the specific IgE values examined, the patient was admitted to the service for a pre-diagnosis of multiple (nuts, cereals, some vegetables and fruits that can be looked at) food allergy and a prick to prick test for verification purposes (Table 1). Skin prick tests were applied to the patient against 31 seasonal fruits and vegetables at 3-day intervals (Figure 1a-c). The prick to prick test results for kiwi, strawberry, banana, orange, tomato, boiled potato, carrot, walnut, apple, lemon, leek, parsley, tangerine, pear, green pepper, lettuce, radish, purple cabbage, corn, cucumber, eggplant, zucchini, cauliflower, cherry, spinach, black cabbage, onion, broccoli, pomegranate and quince are shown in the table (Table 2). Tests against 30 other foods, except boiled potatoes (probably not fresh), were positive. It was found out that when the patient ate foods that were positive for the test, his gastrointestinal complaints were accompanied frequently and more severe.

As a result of these tests, our patient was advised to take a diet for a certain period of time and come for a check-up. The patient who came to the control three months later informed us that he avoided foods that he was considered allergic to as much as possible, the most intense/ severely positive foods, and that this diet itself reduced his complaints, especially abdominal pain, and benefited from the diet.

Afterwards, the patient was fed four strawberries from these foods, for which the skin prick test was significantly positive, and an oral provocation test was performed openly (by knowing what the patient ate). After the first strawberry was eaten without any problems, mild nasal itching and suspicious swelling under the right nipple developed when the second strawberry was eaten. At the time of eating the third strawberry, complaints of itching and mild abdominal pain appeared on the right eyelid and back. Since the patient's complaints were also indefinite and suspicious, the third strawberry was also finished. He also consumed the fourth strawberry without any additional problems. Despite the administration of the fourth strawberry, the complaint of

\section{Table 1. Specific IgE values}

\begin{tabular}{|l|l|l|l|l|}
\hline Specific IgE & ku/L & Specific IgE & ku/L & Specific IgE \\
\hline The panel of nuts & & Grain panel & Meat-fish panel \\
\hline Peanut & 1.67 & Wheat flour & 1.07 & Trout \\
\hline Nut & 1.68 & Corn & 1.91 & Salmon fish \\
\hline Walnut & 0.80 & Buckwheat & 1.79 & Codfish \\
\hline Fruit panel & & Rice & 4.67 & Mutton \\
\hline Orange & 9.70 & Milk-egg & & Red meat \\
\hline Strawberry & 8.98 & Cow's milk & $<0.10$ \\
\hline Banana & 2.42 & Goat's milk & $<0.10$ & Beef \\
\hline Potato & 1.74 & $\alpha$-Lactalbumin & $<0.10$ & Chicken \\
\hline Kiwi & 2.36 & Casein & $<0.10$ & Chotritional allergens \\
\hline Vegetable panel & & Yogurt & $<0.10$ & Cocoa \\
\hline Tomato & 7.85 & Whole egg & $<0.10$ & - \\
\hline Soy bean & 1.41 & Egg yolk & $<0.10$ & Tree pollen \\
\hline- & - & Egg white & $<0.10$ & Platanus tree \\
\hline IgE: Immunoglobulin E & & & & $<0.10$ \\
\hline
\end{tabular}



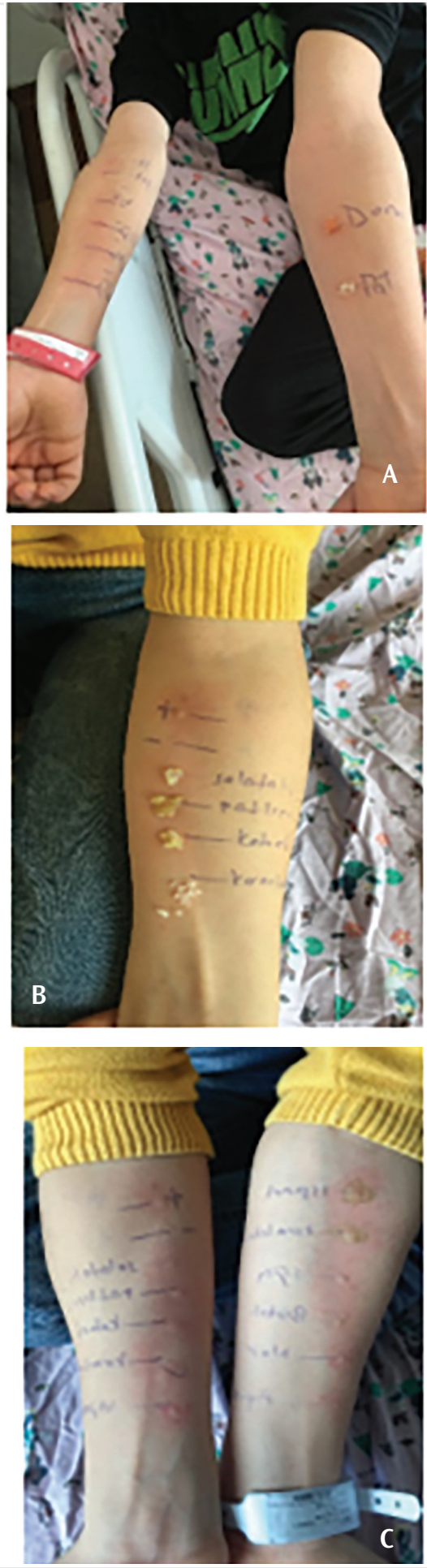

Figure 1. Skin prick-to-prick test performed on different days in our patient $(\mathrm{A}-\mathrm{C})$

abdominal pain remained mild, but the test was not continued. After the test and the next day, there was no increase or change in the complaints, and the abdominal pain completely disappeared.

Our patient was monitored with nutritional recommendations, and in the follow-up, it was noted that along with other complaints, abdominal pain was especially relieved in the patient with diet-appropriate nutrition. Although the PFAS usually forms a phenotype with mild and local oropharyngeal reactions, an adrenaline autoinjector was prescribed for our patient to use as a precaution in case of emergency, although its place in treatment is also controversial. Permission has been obtained from the patient's family for presentation.

\section{Discussion}

Food allergy in children occurs with a frequency of about $6-8 \%$, and in adults with a frequency of $3-4 \%$ (1). It most often begins in the first two years of life. Fresh fruit allergy accounts for $1 / 3$ of them, while vegetable allergy alone is responsible for $7 \%$ of all food allergies (2). Fresh fruit allergy is the most common food allergy that occurs above the age of five. It is known that food allergy to fruits from the Rosaceae family (apples, pears and peaches) develops most often (2). About $30 \%$ of children with food allergies have multiple food sensitivities. As mentioned above, panallergens in children (LTP, profilin, etc) its sensitization (sensitization) is manifested by multiple vegetable-fruit allergies and is frequent $(1,2)$.

OAS is defined as the occurrence of symptoms such as oropharyngeal itching and angioedema in the lips, tongue, palate, ear and throat, which occur in a short time after ingestion of any food. Although it describes the reaction against plant-derived foods in patients with pollen allergy; The nomenclature of PFAS is found to be more accurate today, since systemic reactions can occur even without oral symptoms, although rarer, in these patients (2).

In PFAS, symptoms manifest as lip angioedema, mouth and throat itching, tingling and mild swelling immediately after ingestion of some uncooked fruits and vegetables. The findings result from a contact reaction in the oropharynx. Although oropharyngeal symptoms are seen more frequently, systemic symptoms are seen between 2-10\%. Patients may apply for nausea and abdominal pain (5-7).

In our case, he was allergic to tree and grass pollen, and allergy to many plant foods was detected, and although the oropharyngeal complaints suggestive of PFAS were mild and less noticeable, especially abdominal pain came to the fore. Multiple vegetable-fruit allergies should be kept in mind, among other reasons, even in older patients who present with gastrointestinal complaints such as abdominal pain (5-7).

PFAS is generally considered to be a problem of adults, but it is rare in children. In a cross-sectional study conducted in 267 children aged 6-14 years, the overall prevalence of PFAS was found to be $8.9 \%, 8.8 \%$ in patients with allergic rhinitis, and $9.1 \%$ in asthmatics (7). If a patient has sensitivity to pollen, the prevalence of PFAS has been found to vary between $9.6-12.2 \%(5)$.

In a study conducted on 254 adults in Turkey, the rate of PFAS detected by patients' self-report was found to be $19.3 \%$. Kiwi, peach, tomato, melon and watermelon were found among the most common causes. In the regression analysis, potential risk factors for PFAS were found to be asthma [odds ratio (OR): 2.4] and tree pollen sensitivity (OR: 2.9) (8). We know that our patient had mild allergic rhinitis symptoms in his history.

The gold standard in the diagnosis of multiple food allergies is food provocation tests $(1,2)$. The fact that our patient showed positivity to tree pollen, cereal and grass pollen panels in the skin prick tests and that 
Table 2. Raw (fresh) vegetable-fruit and prick to prick skin test results

\section{Prick to prick test}

\begin{tabular}{|l|l|l|l|l|l|}
\hline Kiwi & $5 \times 5$ & Tomato & $10 \times 5$ & Positive control (histamine)-I* \\
\hline Strawberry & $7 \times 5$ & Potatoes (boiled) & $2 \times 2$ & Negative control \\
\hline Banana & $5 \times 5$ & Carrot & $7 \times 8$ & \\
\hline Orange & $4 \times 4$ & Walnut & $4 \times 4$ & Corn \\
\hline Apple & $3 \times 3$ & Mandarin & $8 \times 5$ & \\
\hline & & & $3 \times 4$ \\
\hline Lemon & $5 \times 5$ & Pear & $3 \times 3$ & Positive control (histamine)-II* \\
\hline Leek & $9 \times 7$ & Green pepper & $5 \times 5$ & \\
\hline Parsley & $5 \times 5$ & Lettuce & $5 \times 4$ & \\
\hline Radish & $6 \times 6$ & Purple cabbage & $4 \times 4$ & \\
\hline Cucumber & & & & \\
\hline Eggplant & $7 \times 4$ & Spinach & $9 \times 6$ & Positive control (histamine)-III* \\
\hline Zucchini & $6 \times 5$ & Black cabbage & $6 \times 5$ & Quince \\
\hline Cauliflower & $8 \times 5$ & Onion & $5 \times 5$ & \\
\hline Sour cherry & $6 \times 4$ & Broccoli & $3 \times 3$ & \\
\hline$*$ Three series of tests conducted on three separate days are shown. All negative controls were $0 \times 0$ mm & $5 \times 5$ \\
\hline
\end{tabular}

he was allergic to different vegetables and fruits shows that our patient complies with the definition of PFAS. Likewise, in the single-blind oral provocation test performed with strawberry, the appearance of the complaints mentioned in the anamnesis confirmed that he had PFAS.

As in our patient, it is essential to exclude responsible foods from the diet in follow-up and treatment (4). As in our case, although it is difficult to diet against everything with multiple vegetable-fruit allergies, it can be done against the most obvious ones, as we have done. It is also reported that allergen-specific immunotherapy for pollen allergy has no place in the treatment of PFAS. Perhaps the benefit of sublingual immunotherapy in LTP syndrome is mentioned (1,2). Recently, although it cannot be used routinely due to its expensiveness, a dietary allergen that cross-reacts with the component-resolved molecular diagnosis method can be found in foods and a dietary intervention directed towards it may be more successful (10). Again, adrenaline autoinjector can be prescribed to the patient, especially for systemic/life-threatening allergic reactions related to LTP or PFAS $(10,11)$.

Children with multiple food allergies should be followed closely in terms of growth and development retardation due to dietary restrictions (1,2). The patient should also be frequently evaluated in terms of asthma, other atopic diseases and inhalant allergen sensitivity $(1,2)$.

\section{Conclusion}

PFAS, which usually presents with mild and local oropharyngeal reactions, should also be considered in patients with multiple vegetablefruit allergies with complaints of abdominal pain.

\section{Ethics}

Informed Consent: Permission has been obtained from the patient's family for presentation.

Peer-review: Externally and internally peer-reviewed.
Financial Disclosure: The author declared that this study received no financial support.

\section{References}

1. Fernández-Rivas M. Fruit and vegetable allergy. Chem Immunol Allergy 2015; 101: 162-70.

2. Fernández-Rivas M, Benito C, González-Mancebo E, de Durana DA. Allergies to fruits and vegetables. Pediatr Allergy Immunol 2008; 19: 675-81.

3. Gupta M, Cox A, Nowak-Węgrzyn A, Wang J. Diagnosis of food allergy. Immunol Allergy Clin North Am 2018; 38: 39-52.

4. Bird JA. Approach to evaluation and management of a patient with multiple food allergies. Allergy Asthma Proc 2016; 37: 86-91.

5. Ivković-Jureković I. Oral allergy syndrome in children. Int Dent J 2015; 65: 164-8.

6. Price A, Ramachandran S, Smith GP, Stevenson ML, Pomeranz MK, Cohen DE. Oral allergy syndrome (pollen-food allergy syndrome). Dermatitis 2015; 26: 78-88.

7. Bedolla-Barajas M, Kestler-Gramajo A, Alcalá-Padilla G, Morales-Romero J. Prevalence of oral allergy syndrome in children with allergic diseases. Allergol Immunopathol (Madr) 2017; 45: 127-33.

8. Özdemir SK, Özgüçlü S. Pollen food allergy syndrome in Turkey: Clinical characteristics and evaluation of its association with skin test reactivity to pollens. Asian Pac J Allergy Immunol 2018; 36: 77-81.

9. Pascal M, Vazquez-Ortiz M, Folque MM, Jimenez-Feijoo R, Lozano J, Dominguez 0 , et al. Asymptomatic LTP sensitization is common in plant-food allergic children from the Northeast of Spain. Allergol Immunopathol (Madr) 2016; 44: 351-8.

10. Ballmer-Weber BK, Hoffmann-Sommergruber K. Molecular diagnosis of fruit and vegetable allergy. Curr Opin Allergy Clin Immunol 2011; 11: 229-35.

11. Webber CM, England RW. Oral allergy syndrome: a clinical, diagnostic, and therapeutic challenge. Ann Allergy Asthma Immunol 2010; 104: 101-8. 